
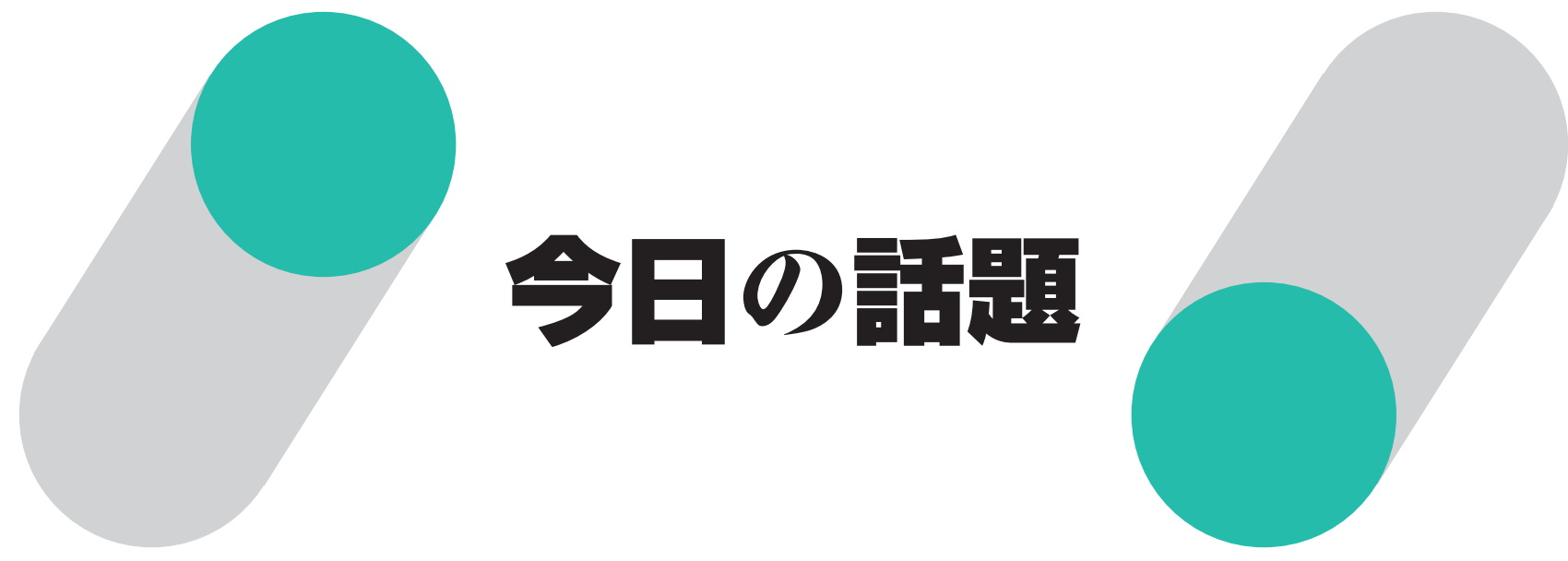

\title{
可溶性支持体による効率的核酸合成技術の開発 核酸創薬の基盤を支える製造技術
}

90 年代以降生命科学の進展は目覚ましく, これらの 技術革新を反映させたゲノム創薬への期待は極めて大き い. 特に, 次世代シークエンサーやマイクロアレイの台 頭によってトランスクリプトーム解析などが広く展開さ れるようになり，パーキンソン病などの神経疾患からが んに至る多くの病態において遺伝子機能の異常が確認さ れるようになった。 また， SiRNAなど，短い核酸分子 が標的遺伝子の発現調節に関与することが発見され, RNAの多様な機能が明らかになるなか, これらの作用 機序に基づく核酸医薬が大きく注目されるようになっ た ${ }^{(1)}$ 。核酸医薬は文字どおり，核酸オリゴマーを有効成 分として目的の薬理作用を発揮しようとするアプローチ であり，アンチセンス，アプタマーなど，多くの薬剤候 補品が開発されている。当然のことながら標的遺伝子を 制御しようとする場合，ペプチド，糖鎖を含む各種天然 物や合成ライブラリーも候補物質として考えられる。し かし，核酸分子は標的遺伝子に対して相補的な塩基配列 をべースに分子設計が可能なため，特異性を獲得するう えで極めて効率的で信頼性が高い. 事実, RNA干渉を 用いた創薬プロセスは，低分子，抗体医薬と比較して， 臨床試験に至る期間が大きく短縮されることが示されて いる ${ }^{(2)}$. とりわけ，従来の医薬品がレセプターや酵素な ど，限られたタンパク質をターゲットにしているのに対 して，核酸医薬は原理的に mRNAがコードしているす べてのタンパク質を標的にでき，これまで治療が困難で あった疾病に対して有効な医薬品を提供することにつな がる. 最近, 細胞膜透過性や酵素耐性など, いわゆるド
ラックデリバリーについても，特定の化学修飾やキャリ ア分子の導入によって解決策が見いだされつつあり，全 身投与可能なアンチセンス医薬品が米国で承認されるな ど，臨床研究でも有效性が実証されるようになってき た ${ }^{(3)}$ 。このような核酸医薬の著しい進展に伴い，低コス トで量産化可能な核酸製造技術が強く求められるように なってきた。本稿では，われわれの開発した合成法が核 酸製造技術にどのように貢献し，量産化の効率化を実現 しょうとしているのか紹介していく.

核酸医薬を製造する技術は，固相法に基づく化学合成 を基盤としている（図1a）。この技術は，ポリスチレン やガラスビーズなど, 不溶性の固相樹脂を用い, ホスホ ロアミダイト化された核酸モノマーを逐次伸長していく 方法である ${ }^{(4)}$ 。この合成システムは，核酸分子を効率良 く提供する技術として自動合成機も開発され，当時の ニーズを十分満たすものであった。しかし，核酸医薬の 開発が広範囲に展開されるにつれ，合成困難な配列や化 学修飾が顕著に増加するようになってきた。ささらに，各 反応工程では大量の洗浄溶媒が必要なうえ, 高価なアミ ダイト試薬を過剰量用いるため，高コストで大量の廃㙌 物を排出する。これらの課題は主に不溶性の固相樹脂に 起因している。つまり，ポリスチレンやガラスビーズは 表面が不均一で反応点が限られているため，基質との相 互作用や接近性が制限され，試薬や洗浄溶媒を過剩量用 いる必要がある。そこでわれわれは，これらの課題を解 決するため “可溶性”支持体を開発することにした ${ }^{(5)}$. 固相法はこれら課題を有する一方, クロマトグラフィな 
a 固相法

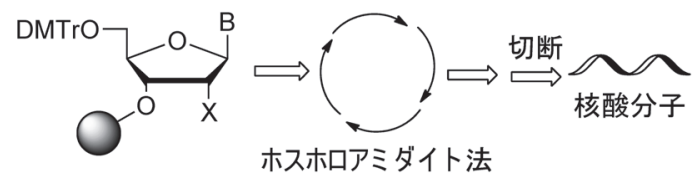

$\mathrm{X}=\mathrm{H}$ or OTBDMS

固相樹脂

ポリスチレン, ガラスビーズなど

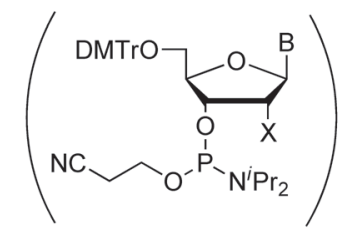

ホスホロアミダイト試薬 b 可溶性支持体を用いた液相法

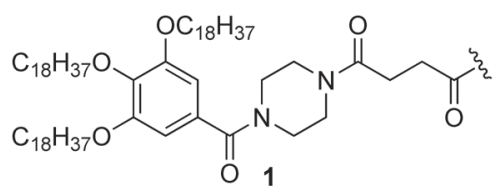

\begin{tabular}{llc}
\hline & 溶媒 & 溶解度 $(\mathrm{mM})$ \\
\hline 1 & $\mathrm{CH}_{2} \mathrm{Cl}_{2}$ & 275 \\
2 & Toluene & 260 \\
3 & $\mathrm{MeOH}$ & 0 \\
4 & $\mathrm{MeCN}$ & 0 \\
\hline
\end{tabular}

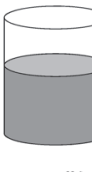

分散

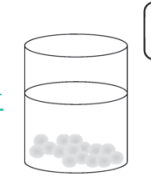

凝集
5'-r(CUUACGCUGAGUACUUCGA)-d(TT)-3'

アミダイト試薬 $1.5 \mathrm{eq}$

カップリング効率 $98 \%$

crude純度 $78 \%$

(1 mmol scale)

\section{図 1 - 核酸合成技術の概要}

a; 固相法：脱トリチル化，カップリング，キャッピング，酸化の4段階を経て，1残基の核酸が伸長する，合成終了後はアンモニア処理に よって，樹脂上から切り出される。 b; 可溶性支持体を用いた液相法：化合物 1 は溶媒選択で分散一凝集を容易に制御できる。 DMTr: ジメト キトリチル，B: 核酸塩基，TBDMS: tert-ブチルジメチルシリル.

ど煩雑な操作を必要とせず，ろ過操作で生成物を分離で きる。これらを考慮した場合，可溶性支持体には，反応 段階では均一分散し反応性を向上させながら，分離段階 では支持体に結合した生成物のみを選択的に凝集・ろ過 できる機能が求められる．種々支持体を合成した結果， 化合物 1 が最も優れた特性を示した（図1b)。この化合 物は, ジクロロメタンなどに高い溶解性を示す一方，極 性溶媒にはほとんど溶解しない。この性質は溶媒組成に よって支持体の分散と凝集を自在に制御できることを意 味しており，反応性向上と分離の簡易化が期待できる. 動的光散乱法を用い化合物 1 の分子挙動を詳細に評価し た結果, $30 \mathrm{~nm}$ 程度の微細粒子として安定に分散してい ることがわかった．この支持体は反応等価性の高い液相 反応系を構築しており，過剩の試薬や副反応の抑制が見 込まれる。これらの結果を受け，化合物 1 を用いオー バーハング領域含む 21 残基 RNAを $1 \mathrm{mmol}$ スケールで 合成することにした (図 $1 \mathrm{~b}$ ，詳細は文献5を参照)。か さ高さの眯念はあるが，市販の 2 -TBDMS 保護アミダイ 卜試薬（1.5〜2等量）でカップリング反応を実施した. その結果, 各段階の平均カップリング効率 $98 \%$, 目的 の核酸配列は純度 $78 \%$ で合成することに成功した，支 持体が結合した各配列の分子量を測定した結果，脱プリ ン化などの副反応がほとんど見られなかったＲNA合 成はしばしば，2'位官能基の立体障害や保護基の脱離が 要因で，欠損配列や純度の低下を引き起こすが，本合成 法はこれらの副反応が観測されなかった。このことは, 固相法に比べ, 工程数が少なく, 高価なアミダイト試薬 が大幅に削減されているため, コスト的に非常に優位性
の高い合成法であることを示している．また，固相法は 合成容量が定型化されたバッチ式を採用しているため, 前臨床，治験へと開発フェーズが進行するにつれ，ス ケールアップに伴う専用装置が必要となり，大きな負担 とリスクを抱えることになる。この問題を解決するた め, 今後, 本液相合成システムをフロー式に応用展開す ることで，さらなる効率的な量産化につなげていきた い.

1) B. L. Davidson \& P. B. McCray, Jr.: Nat. Rev. Genet., 12, 329 (2011).

2) M. López-Fraga, N. Wright \& A. Jiménez: Infect. Disord. Drug Targets, 8, 262 (2008).

3) http://www.fda.gov/NewsEvents/Newsroom/PressAnnouncements, 2013.

4) S. L. Beaucage \& R. P. Iyer: Tetrahedron, 48, 2223 (1992).

5) S. Kim, M. Matsumoto \& K. Chiba: Chem. Eur. J., 19, 8615 (2013).

(金 承鶴, 東京農工大学イノベーション推進機構)

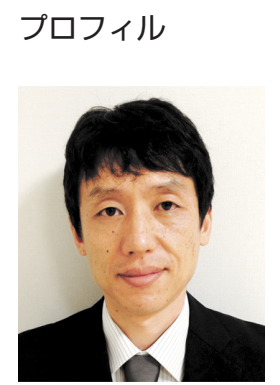

金 承鶴 (Shokaku KIM)

<略歴>1994年東京農工大学農学部応用 生物科学科卒業 $/ 2002$ 年同大学大学院連 合農学研究科博士課程修了, 博士 (農学) / 東京工業大学講師, 東京農工大学博士研究 員を経て，2008年より，東京農工大学特 任准教授 $<$ 研究テーマと抱負 $>$ 新規核酸ア ナログおよび効率的な合成方法の開発、構 造・機能評価＜趣味>読書, スポーツ観戦

Copyright C 2014 公益社団法人日本農芸化学会 